Maurer School of Law: Indiana University

Digital Repository @ Maurer Law

$9-2014$

\title{
Learning from Lin: Lessons and Cautions from the Natural Commons for the Knowledge Commons
}

Daniel H. Cole

Indiana University Maurer School of Law, dancole@indiana.edu

Follow this and additional works at: https://www.repository.law.indiana.edu/facpub

Part of the Intellectual Property Law Commons, and the Scholarly Communication Commons

\section{Recommended Citation}

Cole, Daniel H., "Learning from Lin: Lessons and Cautions from the Natural Commons for the Knowledge Commons" (2014). Articles by Maurer Faculty. 1277.

https://www.repository.law.indiana.edu/facpub/1277

This Article is brought to you for free and open access by the Faculty Scholarship at Digital Repository @ Maurer Law. It has been accepted for inclusion in Articles by Maurer Faculty by an authorized administrator of Digital Repository @ Maurer Law. For more information, please contact rvaughan@indiana.edu. 


\section{Learning from Lin: Lessons and Cautions from the Natural Commons for the Knowledge Commons Daniel H. Cole*}

\section{Introduction}

Legal scholars who write about information and intellectual property (IP), especially those concerned with drawing appropriate boundaries between private and public domains, understandably have been mining the voluminous writings of the late Elinor ("Lin") Ostrom for valuable lessons. Ostrom spent a lifetime studying the wide variety of property regimes used anywhere in the world for governing common-pool resources, primarily (but not exclusively) in the natural world (E. Ostrom 2010a, 2010c). Later in her career, Ostrom contributed applications of her frameworks, theories, and models to what she called the "knowledge commons." (Hess \& E. Ostrom 2007). She recognized the knowledge commons as a separate realm from the natural commons, which would not admit simple transfer of lessons learned from her earlier work, but required systematic study of its own resources, actors, institutions, action situations, and so forth. Each chapter in this book contributes to that systematic study.

\footnotetext{
* Daniel H. Cole is Professor of Law and of Public and Environmental Affairs at Indiana University, Bloomington, Indiana, USA. He is also a member of the Affiliated Faculty of the Vincent and Elinor Ostrom Workshop in Political Theory and Policy Analysis. He is author or editor of seven books, including most recently Property in Land and Other Resources (Lincoln Institute of Land Policy 2012), which he co-edited with Elinor Ostrom.
} 


\section{Governing Knowledge Commons}

This chapter offers guidance to IP scholars who are seeking to adapt, analogize to, or otherwise use Ostrom's work to inform their own research. The main lessons are two: (I) those looking for normative guidance from Ostrom as to the proper structure of IP law are bound to be disappointed (or dishonest); but (2) those looking for conceptual, analytical, and methodological guidance will find it in Ostrom's Institutional Analysis and Development (IAD) framework, which can (a) improve IP scholars' understanding of information and information flows under alternative institutional arrangements; ${ }^{1}$ (b) diagnose problems (or dilemmas) in existing institutional arrangements; and (c) in select cases predict outcomes under alternative institutional arrangements. Even then, normative implications will remain scarce (to nonexistent), and all predictions will be contingent and contestable. No panacean solutions to social dilemmas relating to information will be discovered (Frischmann 2013).

Even analytical lessons from Ostrom's work for IP scholars will be limited, as Madison, Frischmann, \& Strandburg (2010) have observed, by an important distinction between natural common-pool resources and information or knowledge commons, which too often goes unremarked: they are very different kinds of goods, implying different governance mechanisms. Suffice it to say, at this point, that for natural common-pool resources "open access" is nearly always a problem requiring an institutional remedy, whereas in information commons it is a viable (though not necessarily preferable) institutional means of achieving social goals.

\section{IP Scholars Seeking Normative Support from Ostrom's Work Will Not Find It}

Legal scholarship, including in the field of intellectual property (IP), is overwhelmingly normative. Scholars argue about what sets of rules should apply, and who should apply them, to interactions among individuals in society. In IP, nearly all of the biggest questions are normative: What constitutional limits should apply to copyright terms? What should be the scope of private ownership under copyright and patent laws? How best to resolve the tension between creating incentives to innovate, for example, by providing exclusive property rights, and facilitating market competition for the benefit of consumers? What should be the scope of "fair use"? How best to prevent the proliferation of IP

\footnotetext{
${ }^{1}$ By “institutional arrangement," I mean sets of rules implemented through some organizational structure. I generally follow Douglass North's definition of an "institution” as a human-devised rule-whether a formal legal rule or an informal social norm—-for structuring social interactions (North 1990: 3). For North, organizations are not institutions, but amalgams of actors. Elinor Ostrom defined "institutions" variously, but not inconsistently, in her works (see Cole 2013: 390-391). Moreover, as Ostrom points out, her own definitions were consistent with North's understanding of the distinctions between "institutions" and "organizations" (see E. Ostrom 2005: 179). However, in Ostrom's analytical framework, it might sometimes at least be more useful to consider organizations as "action arenas" rather than as actors. For more on "action arenas" as part of Ostrom's analytical framework, see infra.
} 
rights from creating tangled webs that perversely impede further innovations? Which, if any, innovations that contribute to the stock of useful knowledge fall immediately into the "knowledge commons"? Which should never do so?

That IP law is dominated by such normative issues is not surprising. After all, laws are (or embody) norms. ${ }^{2}$ Few other academic disciplines are so heavily normative in focus as legal studies. Most social-scientific disciplines, and scholars within those disciplines, tend to be more analytical than normative in their approaches and methods. ${ }^{3}$

Elinor Ostrom's work provides a veritable model of social-scientific analysis. She focused on constructing empirically informed frameworks, theories, and models that were (I) conceptually clear; (2) thickly descriptive (embracing complexity); (2) diagnostic; (3) analytically rigorous; and (4) integrative of configural interactions among explanatory factors, suggesting patterns of social interactions and their social-ecological consequences - as with the "design principles" from Governing the Commons (E. Ostrom 1990). The integration of explanatory factors might sometimes allow for (tentative) predictions about the (relative) success or failure of similar institutional applications in similar social-ecological circumstances. But rarely, if ever, will a reader of her work come across an expressly normative argument (unless one considers to be "normative" her frequent arguments about the importance of conceptual clarity and interdisciplinary cooperation using multiple methods).

Throughout much of her work, Ostrom evinced one substantive normative commitment to the principle of self-governance, as reflected in the "polycentric approach" pioneered by her husband, the political theorist Vincent Ostrom (V. Ostrom 1999; V. Ostrom, Tiebout, \& Warren 1961; E. Ostrom 2009a, 2009b, 2010b, 2010c, 2010d, 20I2). That approach embodies a normative principle of subsidiarity according to which governance is a "coresponsibility" of units at central (or national), regional (subnational), and local levels (see Decentralization: A Sampling of Omissions). But even that commitment to polycentricism was contingent, context-specific, and focused on matching the scale of governance to the scale of operations appropriate for the particular production or provision problem under investigation. For example, in her early studies of municipal versus neighborhood policing in Indianapolis, Indiana, Ostrom hypothesized that smaller police departments would function more effectively (according to a variable of criteria) than would highly consolidated, metropolitan police departments. But her empirical research revealed that medium-size police departments overall outperformed both smaller (neighborhood) and larger (municipal-level) units (E. Ostrom, Parks, \&

\footnotetext{
${ }^{2}$ More specifically, they are the formal "rules of the game," which, together with informal social norms, structure social interactions (see North 1990: 3).

${ }^{3}$ The recent rise of empirical legal scholarship and other applications of social-scientific methodologies to law have reduced, but not eliminated, the dominance of normative legal scholarship. On the rise of empirical legal scholarship, see, e.g., Heise (2002). On more general applications of social-scientific methodologies to law, see, e.g., Lempert \& Sanders (1986); Monahan \&Walker (2009); Baird, Gertner, \& Picker (1998).
} 
Whitaker 1978). ${ }^{4}$ Thus, polycentricism itself was not immune to Ostrom's oft-repeated injunction that there are no institutional panaceas for resolving complex social dilemmas (E. Ostrom 2007).

Aside from her strong (but contingent) commitment to polycentricism, the relevance of which is unclear in the context of the information or knowledge commons, the goal of Ostrom's work never was to promote specific social outcomes. Though she is sometimes portrayed as an "advocate" for local self-governance using common-property regimes, she really was only a proponent of the $i d e a$ that such governance systems are sometimes successful according to some evaluative criterion, such as sustainability of the resource base over time. As such, she argued that scholars should not summarily exclude, as Garrett Hardin (1968) did, common-property regimes from comparative analyses of alternative institutional solutions to social-ecological dilemmas. ${ }^{5}$ Ostrom did not believe local self-governance was the answer to resource overuse problems any more than public ownership/regulation or private ownership/markets (E. Ostrom, Janssen, \& Anderies 2007; Frischmann 2012). Again, there are no panaceas-no universal, first-best, institutional solutions to inevitably complex social dilemmas (E. Ostrom 20II-20I2; Acheson 20II).

That Elinor Ostrom, like many other social scientists, elevated analytical and methodological considerations over normative arguments creates an insuperable problem for legal scholars who would appropriate her frameworks, theories, and models to further their own normative policy preferences, whether in natural resources law or IP law. It just won't work. No one can point to anything in any of Ostrom's voluminous writings that would support arguments that, for example, IP rights should be more restricted than they are at present or the scope of "fair use" should be broader (or narrower). ${ }^{6}$ Ostrom might (or might not) have agreed personally with those normative assertions, but nothing in her work on local common-property regimes, including the "design principles" she derived in Governing the Commons, supports normative conclusions.

That might seem odd, given that Ostrom's famous IAD framework, which predated Governing the Commons, has a box devoted to "Evaluative Criteria." The purpose of that box was to adjudge, as people inevitably do, social and ecological outcomes of social interactions in which actors, holding designated positions, behave strategically but in general accordance with "rules-in-use."7 It would seem that any such evaluative criteria must

\footnotetext{
${ }^{4}$ More generally, Ostrom and her co-authors found little empirical support for conventional presumptions of constant economies of scale in provision of public services. They found both economies of scale and diseconomies of scale, depending on the types of public services being provided and the circumstances (e.g., community attributes) in which they were being provided.

${ }^{5}$ On comparative institutional analysis, see, e.g., Cole (2013); Komesar (1994); Aoki (200I).

${ }^{6}$ One arguable exception is mentioned in Section 6 below, where I claim that Ostrom (and co-author Charlotte Hess) simply (perhaps "casually" would be a better word) erred in implying that open-access information repositories invariably are a "positive" outcome of collective action and proprietary information systems with gated access invariably are a "negative" outcome. If anything, this example is so exceptional that it proves the rule that Ostrom was exceedingly reluctant to make or support sweeping normative generalizations.

${ }^{7}$ The IAD framework is set out in much more detail, infra.
} 
themselves be normative or at least imply normative consequences. Tellingly, Ostrom herself paid scant attention to the "Evaluative Criteria" box in her IAD framework, but recognized that the box might be populated by various (not necessarily consistent) criteria. For example, she referred to alternative evaluative criteria, including (I) economic efficiency, (2) fiscal equivalence, (3) redistributional equity, (4) accountability, (5) conformance to values of local actors, and (6) sustainability, and noted the need to make trade-offs among evaluative criteria (E. Ostrom 20II). Ostrom's decision to avoid committing to a specific evaluative criterion or set of criteria was quite intentional. Her goal was to provide a framework for analysis consistent with a wide variety of theories and models, which might embody varying normative commitments. Indeed, she contended that her IAD framework was congenial to microeconomic theory, game theory, transaction cost theory, social cost theory, public choice, and constitutional and covenantal theory, along with theories of public goods and common-pool resources (E. Ostrom 2005: 28; Madison, Frischmann, \& Strandburg 2010). Such a diversity of theories could only be compatible with the IAD framework if the framework itself was not tilted to favor one or more of them to the detriment of others. Moreover, as recognized by the editors of this book and incorporated into their adapted version of the IAD framework, Evaluative Criteria often are, or can be, based on the relevant community's explicit (and sometimes implicit) objectives.

The most that can be said is that, in a social-ecological systems context, Ostrom assumed that more robust and resilient resource-management regimes tended to be more successful (perhaps by definition) and, therefore, better. From that point, we might legitimately argue that the "design principles" from Governing the Commons were informed by an implicit normative commitment to long-run sustainability of social-ecological systems-hardly a controversial policy goal in the context of natural resources. Indeed, the widespread agreement about that implicit normative goal of sustainability, among diverse scholars with varying normative commitments, may have enabled Ostrom to pay less attention to "evaluative criteria" than would have been necessary in the absence of such consensus.

III. What IP Scholars Can Learn from Ostrom: Conceptual, Analytical, and Methodological Lessons

Setting normative considerations to one side, Ostrom's work has a great deal to offer IP scholars seeking to understand and diagnose IP problems, and possibly (just possibly) to predict outcomes from interactions under alternative IP arrangements. Indeed, unlike many of her fellow political scientists who have fallen in love with abstract models and statistical analyses for their own sakes, Ostrom was never satisfied if her research did not yield policy-relevant insights. Indeed, she possessed a unique ability to simultaneously combine scientific rigor with policy relevance. But she always was more interested in informing policy, than pushing it in one direction or another. 
In the remainder of this chapter, I will suggest that Ostrom's work offers (at least) two useful and applicable analytical and methodological lessons for IP scholars, including (I) the importance of conceptual clarity, particularly in distinguishing between resource attributes, institutions, and actors; and (2) the IAD framework (or some variant of it) for understanding social interactions structured in substantial part by IP rights. ${ }^{8}$ Using the IAD framework and comparing cases, models, and experimental outcomes might allow scholars eventually (after several years of research design, implementation, data collection, and analysis) to develop something like the "design principles" Ostrom derived for local common-property regimes used to govern common-pool resources. ${ }^{9}$ Such principles might (or might not) facilitate predictions of circumstances in which one combination of public, common, and private rights (and duties) in "common pools" of information might work better (or worse) than alternative combinations. Her primary purpose in setting them out was not to enable prediction but merely to identify "underlying regularities" in local common-property regimes (E. Ostrom 2010a: 16). ${ }^{10}$

\section{A. THE PARAMOUNT IMPORTANCE OF CONCEPTUAL CLARITY}

Legends abound of three-hour (or longer) meetings at Vincent and Elinor Ostrom's Workshop in Political Theory and Policy Analysis at Indiana University devoted entirely to defining a single term or concept. These were not mere scholastic exercises but practical and important efforts to facilitate cross-disciplinary understanding, so that scholars from diverse academic backgrounds (including, but not limited to, anthropology, economics, game theory, history, law, philosophy, political science, psychology, public administration, and sociology), using different analytical tools and methods, could work together effectively to describe, diagnose, analyze, and possibly resolve commons problems. In the absence of an agreed vocabulary—or, at least, clearly defined termscross-disciplinary communication suffers, and progress toward resolving social dilemmas

\footnotetext{
8 The value of the IAD framework already has been recognized by IP scholars writing from various disciplinary perspectives about the information or knowledge commons. See, e.g., Madison, Frischmann, \& Strandburg (2010); Tenenberg (2008); and Schweik \& English (2007).

9 Ostrom's phrase "design principles" can be misleading. She did not mean necessarily to imply either the implementation of a strategic plan or a designer. See Becker \& Ostrom 1995: I22 ("one should not presume that there was a conscious overall plan to develop institutions that met the design principles. Rather, the design principles are an effort of careful observers to identify commonalities that help to account for sustainability of fragile resources over very long periods of time."). Ostrom, herself, has regretted confusion arising from the phrase "design principles" and has suggested "best practices" as an alternative (E. Ostrom 2010c: I4, n.5). However, given the normative implication of the word "best," the substitute phrase might prove just as misleading as "design principles." In any case, a recent meta-analysis testing the "design principles" from Governing the Commons found them robust overall (see Cox et al. 2010).

${ }^{10}$ Perhaps the phrase "underlying regularities" (or "regularly observed characteristics") might be more fitting than either "design principles" or "best practices" for denoting the attributes of successful commons-management regimes.
} 
of shared concern is obstructed. ${ }^{11}$ That concern motivated creation of the Institutional Analysis and Development (IAD) framework, which is addressed in the following subsection. Scholars adopting that framework essentially commit to "a common set of linguistic elements that can be used to analyze a wide diversity of problems," including potentially those relating to the information or knowledge commons (E. Ostrom 20Iob).

Ostrom was not an IP scholar; nor am I. So I will not presume to recommend that IP scholars simply adopt or adapt the shared vocabulary that Ostrom "Workshoppers"12 developed over the course of many years of long and often contentious discussions. Despite Ostrom's goal of generating a shared vocabulary and framework for analysis universally applicable over the wide range of social dilemmas (E. Ostrom 2005: 6), it is entirely possible that the different attributes and issues of the knowledge commons will require deviations from or emendation of existing frameworks and vocabularies. Indeed, the editors of this book have undertaken to adapt Ostrom's IAD framework to the problems of the information or knowledge commons (Madison, Frischmann, \& Strandburg 2010), and this book continues that project. Undoubtedly, however, similar interdisciplinary problems can be expected to arise (if they have not arisen already) among scholars in the "IP wars," who make up an even broader group coming not just from the traditional social sciences and the law but also from informatics, computer science, engineering, and biotechnology.

A few examples might suffice to indicate the types of conceptual issues that require, if not consensus, then at least clarification to allow those various scholars (and non-scholar stakeholders) to understand one another. ${ }^{13}$ For one, IP scholars surely will want to heed Ostrom's caution about the potential for confusing or conflating resource systems (which, in the case of IP scholars, are the information, data, or knowledge) with either the humanly devised institutional settings for managing those resources (e.g., property and regulatory systems) or with the actors who (a) create, innovate, or discover new information (re)sources and/or (b) structure the institutional structures for managing information. ${ }^{14}$ In the natural commons context, we are careful to distinguish

${ }^{11}$ What is achieved in the absence of a clearly defined and agreed-upon vocabulary is what the philosopher David Lewis (1969) referred to as a "babbling equilibrium" (see also Ostrom 2005: 176).

${ }^{12}$ A "Workshopper" is an affiliated faculty member, visiting scholar, graduate student, or staffer in Indiana University's Workshop in Political Theory and Policy Analysis, which in 2012 was named for its founders, Vincent and Elinor Ostrom.

13 Ostrom insisted that everyone should use each term of art, such as "institution," in precisely the same way. For example, Hess \& E. Ostrom (2003: II4) stress the need for "shared meanings." In my view, legitimate reasons exist for scholars to use the same term in different ways, depending on what functions those terms are serving in their analysis. See Cole (2013). However, if social scientists and legal scholars are to tolerate diverse meanings of similar terms, it becomes imperative for individual scholars to define with utmost care terms amenable to multiple meanings in every paper they write. Moreover, even if Ostrom's insistence on "shared meanings" is unduly strict, her goal of achieving widespread, or even universal, agreement of a common framework for analysis and of variables within that framework remains crucial for enabling meta-analyses of case studies and coding for quantitative empirical analysis.

${ }^{14}$ Indeed, some IP scholars already have heeded this lesson. See Madison, Frischmann, \& Strandburg (2010) and this volume. 
common-pool resources (CPRs) - naturally existing systems with various biophysical attributes-and common-property regimes (also CPRs), which are human-created sets of institutions for managing common-pool resources (among others). In the case of the information or knowledge commons, it is equally important to distinguish the information itself, with whatever attributes it might have, from whatever system(s), including IP laws, humans set up to control or manage it and its flow.

Another issue requiring careful attention and clarification is specification of different kinds or types of information and information flows, with diverse characteristics and attributes, perhaps warranting differential governance. Already we have a substantially different governance system, patents, for dealing with certain kinds of scientific information, as compared with artistic information, which is governed by copyright law (or sometimes placed in the "creative commons"). Trade names, trade secrets, fiduciary and other privileged communications, evidence submitted under oath, computer code, and many other types of information and flows are all dealt with in various ways in the legal system.

Likewise various fora of information exchange, such as e-mail, telecommunications, police interrogations, court sessions, legislative and administrative committee hearings, face-to-face business meetings (with or without written minutes), and personal communications are subject to very different kinds of procedural and sometimes substantive rules (not to mention informal social norms). Much has been written already about all of these types of information and information-exchange by scholars and advocates (occasionally one and the same) from various disciplines and a variety of perspectives. Much work remains to be done, however, to systematize and meta-analyze this vast quantity of "data" so as to develop the kinds of theories and "design principles" that Ostrom and her colleagues painstakingly developed and applied over the course of decades, with some measure of success, to specifying and diagnosing problems of the natural commons. The existing IAD framework (or some variation on it) could be very useful to such an effort, and the adapted IAD framework developed and applied in this book paves the way.

\section{B. POTENTIAL FOR APPLYING THE IAD FRAMEWORK TO THE}

\section{INFORMATION OR KNOWLEDGE COMMONS}

As noted earlier, the IAD framework originally was created in large part to facilitate scholarly cooperation by providing a common framework based on a shared vocabulary that would be amenable to diverse assumptions, theories, and models of social interaction. The framework itself is deceptively simple in design, but allows for detailed analyses of highly complex interactions of however many variables (and subvariables) are of interest. It is the most widely used framework in studies of the natural commons (Constantinidis 2012), and has been cited as one of the most important analytical tools of the policy process (Sabatier 2007). As a legal scholar, I have long wondered why a framework so obviously congenial to legal analysis has not found wider application in my own field 
(including, I confess, in my own work). Perhaps it is due to the overwhelming normativity of legal scholarship, discussed earlier. Regardless, IP scholars (lawyers and nonlawyers alike) should find the IAD framework an immensely useful tool for disentangling the various elements that make up social problems relating to information and information flows, understanding those elements, and diagnosing more precisely where the roots of problems lie, enabling (but never guaranteeing) collective action to resolve those problems via new or amended institutions.

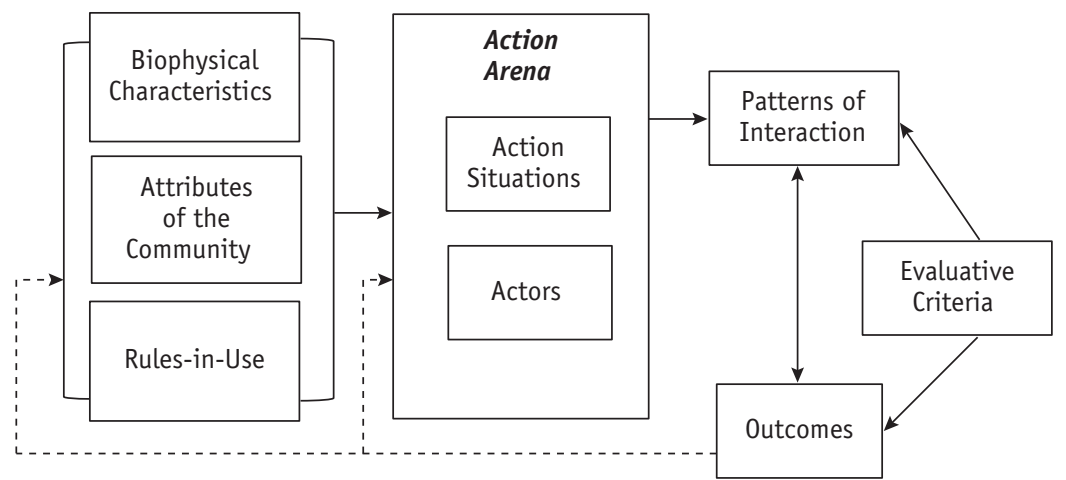

FIGURE 2.I Institutional Analysis and Development Framework.

Source: Elinor Ostrom \& Charlotte Hess, A Framework for Analyzing the Knowledge Commons, in Understanding Knowledge as a Commons: From Theory to Practice 44, Fig. 3-I (Charlotte Hess $\&$ E. Ostrom eds., MIT Press 2007).

Several, marginally different, versions exist of the IAD framework. The version discussed below is fairly standard, and comes from Elinor Ostrom and Charlotte Hess's initial efforts to extend the commons framework to the "knowledge commons."

\section{Biophysical Characteristics and Different Types of Goods}

Starting with the three boxes vertically aligned along the left side of the framework, the "Biophysical Characteristics" of the resource probably have less significance for information than for a natural commons. After all, ideas have no biophysical attributes (unless we treat them purely as electrical or chemical outputs of cognition via neurotransmission). Nevertheless, Ostrom and co-author Charlotte Hess identified several bases for distinguishing varying physical characteristics of information: facilities through which information is accessed, including bookstores, libraries (public, academic, or private), newspapers, the Internet (including both open-access and subscription-based sources of various kinds); artifacts, which are the discreet physical forms through which information flows and in which it is accessed, including maps, books, and computer files (to name just a few); ideas themselves, which are the "nonphysical flow units" of the resource (E. Ostrom \& Hess 2007: 47-48). Obviously, much more work remains to be done 


\section{Governing Knowledge Commons}

elaborating on these tentative categories, and IP scholars (along with others who work in fields diverse as cognitive psychology, informatics, and semiotics) are better positioned to carry out this work than those of us who focus on natural resources.

Related to the discussion of "biophysical characteristics" is a tricky problem of defining just what kind of good (if it is a single kind of good) information actually is. Widespread agreement seems to exist that ideas, once they are released into the world from any source, are in the nature of pure public goods. They meet the strict conditions of nonrivalrousness in consumption and nonexcludability. Very few other public goods (or goods with public attributes) are so pure. Even goods traditionally thought to be virtually pure public goods, such as sunlight, lighthouses, and the atmosphere, are less pure public goods than ideas. Solar access disputes have shown that sunlight can, in some circumstances, be rivalrous in consumption. ${ }^{15}$ Ronald Coase has argued that, in special cases at least, the external benefits provided by lighthouses can be recaptured by suppliers (Coase 1974; but see Van Zandt $\left.1993^{16}\right)$. And since the industrial revolution it has become clear that the atmosphere, like waters, forests, and other natural resources, is at best an impure, subtractable, or congestible public good. As such, these resources fall somewhere on the spectrum between public goods, as technically defined, and club or toll goods. It is such impure public goods to which Ostrom assigned the label "common-pool resources" (Ostrom \& Ostrom 1999: 75). She spent no time studying pure public goods, which by definition are not candidates for the "tragedy of the commons" because they would survive, undiminished, regardless of whatever institutional structures were introduced to sustain or exploit them. It is doubtful, however, that any natural resources actually meet the strict requirements of nonrivalrousness and nonexcludability.

To the extent information (in the raw form of "ideas") is a pure public good, the implications for governance are quite different from the case of common-pool natural resources, where "open access" (at least where demands on the resource are increasing relative to supply) leads inexorably to "tragedy," as Hardin surmised. All solutions to the "tragedy of the commons" involve the replacement of open access with restricted access and use via private property, common property, or public property/regulatory regimes (Cole 2002). Open access (signifying the absence of restraints on access and use) is always the socially optimal governance system for existing pure public goods simply because it is inevitable under conditions of nonrivalrousness and nonexcludability. Consequently, if IP scholars were concerned only about information in its purest form-as ideas-then neither Ostrom's analytical framework nor any other approach would be at all useful

\footnotetext{
15 See, e.g., Prah v. Maretti, 108 Wis. 2d 223, 321 N.W.2d I82 (1982); Fountainebleau Hotel Corp. v. Forty-five Twenty-Five Inc., II 4 So. 2 d 357 (Fla. App. 1959).

${ }^{16}$ Van Zandt claims that Coase was describing a special case because such a high percentage of global shipping traffic used the Port of London during the period Coase was describing, and notes that the government subsidized private provision of lighthouse services by giving lighthouse owners taxation powers in the Port of London.
} 
because no social dilemmas (or governance problems) would exist. However, that is not the prevailing situation.

In fact, IP institutions matter a great deal not because of the ideas themselves (although IP policy rightfully is concerned with incentives for the production of ideas, especially those that contribute to the "stock of useful knowledge" (Kuznets 1965: 85-87)) but with what we might call, to borrow a phrase from mythology and semiotics, "ideas-in-form"ideas as represented in texts, pictures, symbols and marks, scores or recordings, codes, and so forth. These are what Ostrom and Hess call "artifacts." In contrast to the ideas they contain, the artifacts are not pure public goods; in fact, some of them, such as closely held secrets (think of the formulae for the original Coca-Cola or Kentucky Fried Chicken), are more nearly pure private goods than any kind of public goods. ${ }^{17}$ Other artifacts, such as books, are not so easily subjected to institutional control because, even though exclusion is relatively easy, they remain relatively nonrivalrous in consumption. Books are easy to resell, gift, or lend, so that the ideas they contain can be freely accessed by many (with no diminution in the amount available for anyone else to consume, so long as the book itself remains intact). Nonetheless, institutional arrangements can, with greater or lesser success, control the flow of ideas themselves by controlling access to and use of the artifacts that contain them as well as the "facilities" through which information is accessed. In addition, by controlling the flow of ideas, institutions (including IP rights and duties) can impact the rate of production, and/or the direction, of new ideas, as in the case of alleged "patent trolls" (compare Magliocca 2013 and McDonough 2006).

\section{Attributes of the Community}

The middle box on the left of the IAD framework, labeled "Attributes of the Community," arguably requires fewer adjustments in the move from the natural commons to the knowledge commons. As already noted, the relevant community of the information or knowledge commons is much larger than most of the communities with whom scholars of the natural common-pool resources have dealt. Indeed, moving the IAD framework from the resource commons to the knowledge commons involves a wholly new participant of central concern: the creator (or producer). Typically, a natural common-pool resource has no human producer. ${ }^{18}$ Thus, the position of "creator" has not been encountered by scholars employing the IAD framework. The various other "actors" are more familiar,

\footnotetext{
17 The ideas contained in the formulae are public goods, but the formulae themselves (the "artifacts") are private goods because of ease of excludability, even if they might in theory be nonrival in consumption.

18 Artificially created "natural" commons do exist; think of stocked fisheries. Moreover, I can easily imagine a philosopher arguing that even what counts as a "natural resource" is, in part, a product of human conceptualization. Thus, all common-pool resources would be at least coproduced or co-created by humans. But I suggest we cabin such issues for purposes of the current discussion, where the distinction between humans as creators of natural and creators of artificial resources seems important regardless of the relation between humans and natural resource systems.
} 


\section{Governing Knowledge Commons}

including providers, financers, distributors, millions of potential or actual users, and of course policy makers who establish "rules of the game" for information production, provision, distribution, and consumption.

It is, to repeat, an unusually large community compared to those traditionally studied by Ostrom and other students of the natural commons. Although, problems of the global commons, such as climate change, certainly would challenge the information commons for size and variety of attributes, including number of actors. It is worth observing that Ostrom wrote a good deal about climate change in her later years, but never attempted to apply the IAD framework to that problem of the global commons (see Ostrom 2012; E. Ostrom 20roa). Was she daunted by the scale of the application ${ }^{19}$ If so, might her reluctance signify the scale of the challenge IP scholars face in applying the framework to the information commons? It is worth noting in this context that the few efforts to apply the IAD framework in the realm of the information or knowledge commons so far have focused on discrete subparts of the problem or applied only subparts of the IAD framework, which seems sensible and perhaps inevitable (see Tenenberg 2008 (a full application of the IAD framework to a case study of student software teams in an undergraduate course at the University of Washington, Tacoma); Schewik \& Kitsing 20 ıо (an application of one important aspect of the IAD framework, the various kinds of rules that apply in action arenas or situations, to open-source governance systems)). This book reflects the most significant effort yet to adapt, extend, and apply the IAD framework to the knowledge commons, and in doing so, much more attention is directed toward analysis of the various communities involved.

\section{Rules-in-Use}

Little needs to be explained to legal scholars (at least) about the box at the bottom-left of the IAD framework, other than that the concept of "rules-in-use" occasionally misleads some social scientists into believing that the "rules-in-form" - the formal legal rules—do not matter at all, as if they could not even influence the rules-in-use (Kinston \& Caballero 2009: I5 8 (mistakenly but approvingly attributing to Ostrom a belief that rules-in-form are "dead letters," while rules-in-use are "rules which are actually followed")). Certainly since Robert Ellickson's famous book on the cattle ranchers of Shasta County, California (Ellickson 1991), if not earlier (Pound I910; Llewellyn 1949; Friedman 1975), legal scholars have understood the important and highly variable relations between formal legal norms and informal social norms. IP scholars have noted, for example, a disjunction between formal legal rules barring Internet file sharing and social norms of sharing among Internet users (Feldman \& Nadler 2006). But no legal scholar doubts that the formal legal rules remain very important (if not always the most important institutional variables).

\footnotetext{
${ }^{19}$ I hasten immediately to cast doubt on the implicit assertion by observing that Elinor Ostrom was not daunted by much of anything during the course of her long career. It is entirely possible that she did not apply the IAD framework to the problem of the "climate commons" merely for lack of sufficient time, given her other innumerable obligations.
} 
The question remains, where do the rules (in form or in use) come from? They are the outcomes (or outputs) of prior action situations taking place at various levels. Constitutional-level interactions result in meta-rules (which may or may not be codified in a single document called a "constitution"), rules that establish processes and procedures for adopting collective choice-level rules (statutes, decisions, administrative rules, etc.). Collective choice-level arenas include (but are not limited to) courts, legislative bodies, administrative agencies, corporate board rooms, club committees, school boards, church conclaves and synods, faculty meetings, and the family kitchen. Rules adopted in those arenas structure everyday interactions at the "operational level." Even at that level, however, rule making goes on. Social norms, which may be as or more powerful than formal legal rules, emerge from regularized patterns of interaction in operational-level situations. The scholar's task, in applying the IAD framework, is to determine, and diagnose perceived problems with, the rules-in-use that govern day-to-day ("operational-level") interactions in the action situations under study. In the IP context, this might be a slightly easier chore than in many natural commons contexts, where determining the rules requires close observation of, and interaction with, local communities for long periods of time. As a highly top-down system of governance, the basic contours of the rule-structure governing various types of information can be discerned from studying national statutes and cases brought under those statutes. In other words, the relative lack of polycentricity in the IP governance system should make it, all else being equal, an easier governance system to comprehend.

In 2005, Ostrom and her Workshop colleague, Sue Crawford, classified (functionally) various types of rules that apply in action situations (E. Ostrom \& Crawford 2005: I86215) including the following (incomplete list):

\begin{tabular}{|c|c|}
\hline Position rules & $\begin{array}{l}\text { Define positions that actors hold, including as owners of property rights } \\
\text { and duties. }\end{array}$ \\
\hline \multirow{5}{*}{$\begin{array}{l}\text { Boundary } \\
\text { rules }\end{array}$} & Define: (I) Who is eligible to take a position; \\
\hline & (2) The process for choosing who is eligible to take a position; \\
\hline & (3) How actors can leave positions; \\
\hline & (4) Whether anyone can hold multiple positions simultaneously; \\
\hline & (5) Succession to vacant positions. \\
\hline Choice rules & $\begin{array}{l}\text { Define what actors in positions must, must not, or may do in their } \\
\text { position and in particular circumstances. }\end{array}$ \\
\hline $\begin{array}{l}\text { Aggregation } \\
\text { rules }\end{array}$ & $\begin{array}{l}\text { Determine whether a decision by a single actor or multiple actors is } \\
\text { needed prior to acting at a decision point in a process. }\end{array}$ \\
\hline $\begin{array}{l}\text { Information } \\
\text { rules }\end{array}$ & $\begin{array}{l}\text { Specify channels of communication among actors, as well as the kinds of } \\
\text { information that can be transmitted between positions. }\end{array}$ \\
\hline Payoff rules & Assign external rewards or sanctions for particular actions or outcomes. \\
\hline
\end{tabular}




\section{Governing Knowledge Commons}

Ostrom (2005: 189, Fig. 7.I) provides the following graph to illustrate how the various rules affect activity within the action arena or situation.

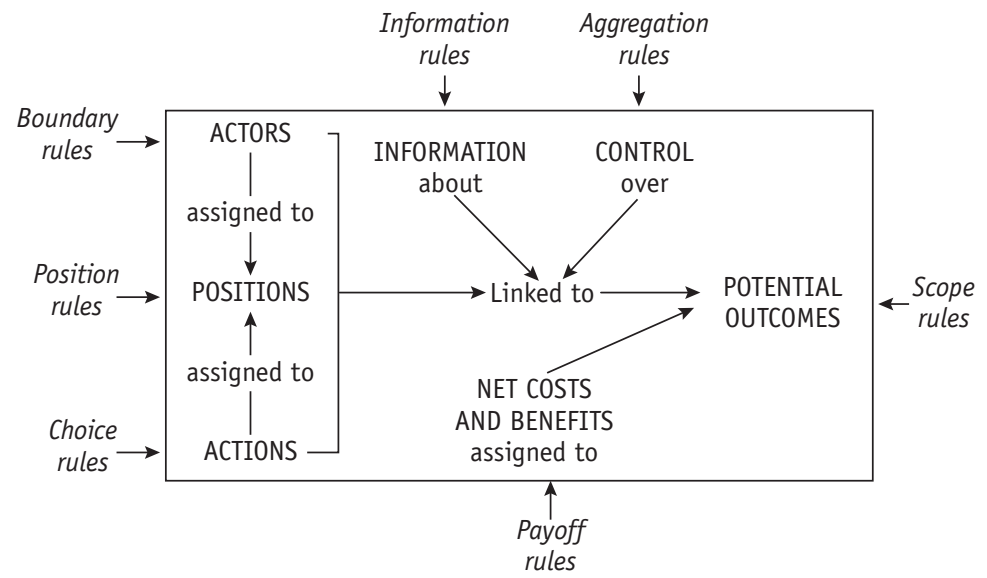

FIGURE 2.2 Rules as Exogenous Variables Directly Affecting the Elements of an Action Situation. Source: Elinor Ostrom, Understanding Institutional Diversity i89, Fig. 7.I (Princeton University Press 2005).

Among the more significant positional rules, for both natural commons and the information or knowledge commons, are property rights and duties. In 1992, Ostrom and Edella Schlager identified several components of private property ownership (Schlager \& E. Ostrom 1992: 250-51; compare with Honoré 1961: 107, identifying nine distinct rights and two duties in the full, "fee simple" ownership):

\begin{tabular}{|l|l|}
\hline Access & $\begin{array}{l}\text { Right to enter a defined area and enjoy its benefits without removing any } \\
\text { resources. }\end{array}$ \\
\hline Withdrawal & $\begin{array}{l}\text { Right to obtain specified products from a resource system and remove } \\
\text { that product from the area for prescribed uses. }\end{array}$ \\
\hline Management & $\begin{array}{l}\text { Right to participate in decisions regulating resources or making } \\
\text { improvements in infrastructure. }\end{array}$ \\
\hline Exclusion & $\begin{array}{l}\text { Right to participate in the determination of who has, and who does not } \\
\text { have, access to and use of resources. }\end{array}$ \\
\hline Alienation & $\begin{array}{l}\text { Right to sell, lease, bequeath, or otherwise transfer any or all of the } \\
\text { preceding component rights. }\end{array}$ \\
\hline
\end{tabular}

\section{Not "Exogenous Variables" but "Initial Conditions"}

One further point of clarification about the three boxes on the left side of the IAD framework needs to be made before we bring them, as inputs, into the action arena or 
situation: Ostrom sometimes referred to those three boxes as "exogenous variables" (E. Ostrom 2005: I5, Fig. I.2). But that is inaccurate. Because of the recursive nature of the framework-feedback from outcomes of action situations effects, either directly or mediated through evaluative criteria, resource attributes, community attributes, and rules-in-use-they are endogenized within the framework. At best, they constitute sets of "initial conditions" immediately preceding any particular social interaction. It might make even more sense to say that they are the prevailing conditions (or "entry conditions") upon a social interaction. ${ }^{20}$

\section{The Action Arena (or Situation): Where Collective Action Happens (or Not)}

The action arena (or situation) is where social interactions occur. It is the place-often these days a virtual place-where: individual actors make decisions that affect social welfare; collective action succeeds or fails; rules are made; entitlements to resources are allocated; exchanges take place (or not); and disputes are adjudicated. If and when institutional change occurs, it occurs in action arenas or situations (Hess \& E. Ostrom 2007: 54).

As already noted, action arenas or situations exist at three different levels of governance in the IAD framework: the constitutional-choice level, the collective-choice level, and the operational level. And what happens in various action arenas at those different levels impacts on relevant resources (e.g., how information is provided, to whom, and under what circumstances), attributes of the relevant community, and the rules-in-use (both formal and informal). Ostrom and Hess, for example, have used the creation of digital repositories of scholarship to exemplify how rule systems are created through collective-choice interactions, and affect the incentives of individual actors in operational-level interactions (Hess \& E. Ostrom 2007: 54-57).

The individual actors participating in action arenas or situations are typically presumed to be either completely or boundedly rational (following Herbert Simon, who greatly influenced Ostrom's work) (Simon 1972: 16I), depending on the theory-based preference of the analyst; either way, actors can be expected to behave strategically to further their own interests (as subjectively determined). This feature makes Ostrom's IAD framework almost uniquely compatible with multiple theories and models, including: neoclassical theory, game theory, public choice theory, and behavioral economics, with the exception of (usually deterministic) models of irrational behavior (see, e.g., Berridge 2003: 17).

Pursuant to rules discussed above, actors in action arenas hold a variety of "positions," depending on the choice-level (constitutional, collective-choice, or operational). At the constitutional level, they may be appointed members of the constitutional convention, members of state ratifying conventions, journalists, scholars, members of interest groups

\footnotetext{
${ }^{20}$ Madison, Frischmann, \& Strandburg (2010) modify the IAD framework in part to account for the complex feedback mechanisms and interactions across the framework components in the knowledge commons context.
} 
attempting to affect the outcomes of constitutional negotiations, judges determining compliance with constitutional process rules, and so forth. At the collective-choice (or policy) level, positions include legislators (junior and senior) with various congressional or party leadership roles, as well as committee assignments and positions, legislative and committee staff members, lobbyists, hearing witnesses, parliamentarians, official reporters, and journalists, among others. In operational-level action arenas, participants include buyers, sellers, owners, renters, contractors, disputants, fiduciary, beneficiary, player, coach-the whole panoply of roles that humans take on in social interactions of all kinds in everyday life.

Operating within the scope of their respective positions (that is, according to the rules), and strategically according to their own (boundedly) rational interests and preferences (as they subjectively see them), actors choose among available action alternatives in light of information they possess about how potential actions (as well as inaction) link to potential outcomes, including costs and benefits (McGinnis 2011: 173-74). In addition to the costs and benefits internalized to the individual actors, their individual decisions may well have social consequences, entailing significant net costs or benefits for the community. Indeed, if that were not the case, society would not confront any social-cost or public-goods problems (broadly put, social dilemmas) requiring collective action.

Studying social interactions at constitutional, collective-choice, and operational levels allows scholars to observe regularities (and irregularities) in patterns of interaction. In many cases, regularized patterns of interaction will represent an equilibrium (although not necessarily a unique, efficient, or Nash equilibrium) for the actors. In other cases, the equilibrium might be difficult to discern or, in especially conflicted and contested situations, might not actually exist (even over long periods of time). When an equilibrium or regularized pattern of interactions is observed,patterns of interaction themselves may constitute or reflect norms of social behavior previously known (from the "rules-in-use" box) or unknown. Most importantly, apparent equilibria may be subject to shocks (exogenous or endogenous) that can alter patterns (or norms) of interaction, depending on their robustness and resilience.

\section{Outcomes}

In a sense, observed patterns of interaction are outcomes of social interactions. For example, in the legal action situation of automobile accident disputes, out-of-court settlements are both an observed regularity of interactions among actors (or parties) and outcomes of the proceedings (Ross 1980: 179 (2,123 of 2,216 cases disposed of by settlement before trial)). Similarly, in the legislative action arena of Congress, the so-called "Mickey Mouse rule" of IP policy, whereby Congress extends copyright terms retroactively whenever the Disney character Mickey Mouse is about to fall into the public domain, reflects an observed regularity of interactions (among players including legislators, lobbyists, and expert witnesses), amounting to an equilibrium situation (which is not to say the 
equilibrium necessarily is efficient) (see, e.g., Posner 2003). That pattern of interaction is itself a predictable outcome of the structure of interests and incentives created by existing sets of institutions (pursuant to theories of public choice) (Landes \& Posner 2004). Meanwhile, the equilibrium patterns of interaction yield predictable outcomes of specific legislative processes to extend the copyright law at regular intervals.

Importantly, outcomes of interactions frequently entail effects that extend beyond the interacting parties to the broader society. So, in a natural commons setting outcomes frequently include consequences for the resource systems and resource units themselves, as well as for those who use the resources (on a broad interpretation of the word "use"). A collective choice-level interaction that displaces "open access" governance with "regulated access and use" naturally would entail outcomes for the relevant resources and users beyond any observed pattern of social interactions in the action arena. In the same vein, a collective-action decision to enclose completely the information commons (e.g., by prohibiting the creation or maintenance of a "creative commons") would produce various predictable and unpredictable outcomes relative to the production and dissemination of information.

Ostrom and Hess provide an unfortunately misleading table of "potential positive or negative outcomes in various knowledge commons" (Hess \& E. Ostrom 2007: 6I, Table 3.I), which conflates outcomes with normative evaluations of those outcomes. For example, they treat enclosure as a "negative" outcome and maintenance of an information commons as a "positive" outcome. This is presumptuous (and as noted above, contrary to their usual practice). It certainly is true that enclosure is an outcome of a proprietary (and gated) scientific database, and "open access" likewise is a consequence of an "open access research library." However, whether one institutional arrangement is "positive," "negative," or preferable is a decidedly normative evaluation for which Ostrom and Hess provided no analysis. They should have been more circumspect. Normative assessments of outcomes as "positive" or "negative" will always be in the eye of the beholder, depending on her or his preferences, interests, and subjectively chosen (but hopefully expressly manifest) "evaluative criteria." Even from a social perspective, a normative assessment of outcomes depends on the selection and application of inherently contestable evaluative criteria.

In other words, the IAD framework itself provides no greater basis for normative presumptions about alternative governance systems for information than it provides for normative presumptions about alternative governance systems for natural common-pool resources. Depending on what function we are trying to maximize, it is entirely possible that neither entirely closed-access nor entirely open-access information systems would maximize it. From a social welfare perspective, some combination of open- and closed-access is overwhelmingly likely to be more socially efficient than complete openor close-access (David 2003: 19). The trick, of course, would be getting the combination just right. And, again, the IAD framework itself will not help that determination, except to the extent applications of the framework result in meta-analyses that yield something 


\section{Governing Knowledge Commons}

like the "design principles" Ostrom derived in Governing the Commons. In addition, the IAD framework can be said to facilitate evaluation by making it easy for evaluators to separate out the various elements that combine to affect outcomes.

\section{Evaluative Criteria}

In applying the IAD framework, we should not simply assume one or another social goal. It might or might not be social efficiency (on some definition). The "evaluative criteria" box in the IAD framework has long been the most neglected and underdeveloped element of the framework. Even in her most elaborate account of the IAD framework, in Understanding Institutional Diversity, Ostrom devotes only three pages to a discussion of the "evaluative criteria" box, and offers only some general contenders for populating it, including (I) economic efficiency; (2) fiscal equivalence; (3) redistributional equity; (4) accountability; (5) conformance to values of local actors; and (6) sustainability. In the more specific context of the knowledge commons, Ostrom and Hess suggest (without citation) that six evaluative criteria are "frequently used": (I) increasing scientific knowledge; (2) sustainability and preservation; (3) participation standards; (4) economic efficiency; (5) equity through fiscal equivalence; and (6) redistributional equity (Hess \& E. Ostrom 2007: 63). They devote a paragraph to describing each discrete criterion (or set of criteria), amounting to just over three pages, without any detailed analysis of how any of the criteria would actually operate within the context of action situations, either separately or in combination with other evaluative criteria.

Ostrom's lack of detailed and critical attention to the "evaluative criteria" in the IAD framework may reflect, more than anything else, her focus on natural common-pool resources, where little (if any) disagreement existed among diverse scholars about the ultimate goal, which was universally assumed to be long-run resource sustainability. Ostrom, Hardin, Demsetz, and virtually every other scholar writing about common-pool resources concurs in ultimate aim, no matter how strongly they disagree about institutional means of achieving it. Consensus about ends makes for easier agreement on evaluative criteria for assessing alternative means (including privatization, public/state regulation of access and use, or local, common-property management) in various circumstances.

In other realms to which the IAD framework might usefully be applied, including the information or knowledge commons, there is unlikely to be agreement with respect to ultimate social goals. Some may argue that the ultimate goal of IP law is to reward innovators, in accordance with well-established property theories based on labor and just deserts, regardless of social welfare (Hughes 1988). Others might argue that the ultimate goal is to build the stock of useful knowledge to facilitate economic growth (representing a social-welfare function) (Kuznets 1965). Still others might assert that the goal is to disseminate knowledge as widely as possible for its own sake (Hettinger 1989; Boyle 2003; but see Wagner 2003 (arguing that strong IP rights are more likely to ensure a flourishing public domain of ideas)). 
In the absence of consensus about ultimate ends, agreement on evaluative criteria for assessing means is unlikely (to say the least). As a consequence, individual scholars have greater freedom to select from among alternative evaluative criteria (at least within some conventional range) for adjudging the outcomes of social interactions. However, that freedom should be constrained by the general scientific principle that evaluative criteria must be clearly specified along with reasons for preferring them, either across the board or in the circumstances, so that the basis for evaluation can be understood and/or contested.

Somewhat more hopefully, scholars of the information commons, like scholars of the natural common-pool resources, might achieve consensus on a certain maximand (e.g., an agreed social-welfare function) for information and information-flows in society, which would enable a more fruitful focus on alternative institutional means of achieving that goal. Alternative presumptions and hypotheses about relations between institutional means and social outcomes could then be subject (at least potentially) to testing and comparison across runs of cases, as Ostrom did in Governing the Commons and her earlier studies of police department performance relative to size.

Finally, the evaluative criteria (however chosen) provide a basis for interpreting as well as evaluating outcomes. Those interpretations and evaluations become part of the feedback loop into resource systems, community attributes, and rules-in-use. When members of the relevant community evaluate outcomes of social interactions as "bad" (according to whatever criteria), they may push (successfully or unsuccessfully) for further action in subsequent action situations at the collective-choice level, to alter or curtail "bad" outcomes. Thus, the recursive aspect of the IAD framework accounts for institutional change (or inertia) over time (even though the framework cannot by itself determine, ensure, or even predict institutional change).

\section{Conclusion}

IP scholars already have begun applying the IAD framework to good effect. Charlotte Hess, writing with Elinor Ostrom and on her own, has been a pioneer in calling for application of the framework to problems of the information or knowledge commons (see, e.g., Hess \& E. Ostrom 2003, 2006, 2007; Hess 2005, 2008). Charles Schweik has applied the IAD framework to "software commons" (Schweik 2005; Schweik \& English 2007). Josh Tenenberg has applied it to study software development teams (Tenenberg 2008). And Jorge Contreras, in this volume and elsewhere, applies the IAD framework to the "genome commons" (Contreras, this volume, ch. 4; Contreras 20II). Other scholars might examine these groundbreaking efforts to assess whether the framework might usefully be applied to their own problems and projects.

These are still early days in the social-scientific study of information as a good, whether public, common, or private. But, as noted earlier, students of the information or knowledge commons should not expect quick and decisive results about appropriate governance 


\section{Governing Knowledge Commons}

institutions. That is one of the chief lessons of the large and growing literature on natural common-pool resources. After several decades of data collection and careful construction of analytical frameworks, theories, and methods to analyze and diagnose commons problems, much has been learned but probably not nearly as much as remains to be learned.

Thanks primarily to Elinor Ostrom and her colleagues at the Ostrom Workshop in Political Theory and Policy Analysis, we have learned that common-property regimes are a viable third category of governance regimes for successfully managing natural common-pool resources over long periods of time. ${ }^{21}$ And we have gained some idea of the conditions under which common-property regimes seem more or less likely to succeed based on the "design principles" Ostrom derived from her meta-analyses of hundreds of individual cases. Since then, despite increasing data collection and efforts to improve analytical methods, further progress toward understanding and diagnosing (let alone resolving) commons problems has been marginal (though hardly insignificant).

Scant reason exists to expect easier and more rapid progress toward describing, diagnosing, and explaining issues relating to information and information-flows. Indeed, as noted earlier, important questions remain about just how applicable the existing literature of natural common-pool resources is to the information commons. Even when information arises or is placed in common pools, it may not have the same kinds of attributes of natural resources found in common pools. As defined many years ago by Vincent and Elinor Ostrom, common-pool resources share certain attributes with public goods, but are not themselves pure public goods. Specifically, they lack nonrivalrousness in consumption, which is to say they are subtractable or congestible. This is not true of information (though it may be true of the various vehicles by which information is provided or disseminated). Thus, whereas "open access" is potentially tragic, and only very rarely preferable, ${ }^{22}$ for a natural resource commons, IP scholars often make arguments promoting "open access" (see, e.g., Willinsky 2006; Swan 2007). And those arguments make sense in that context (even if they are not completely convincing) to the extent that information approximates a pure public good.

Even if the natural resource commons and the information commons were more similar than they are, IP scholars hoping to find support for normative arguments about the preferability of common-property management (let alone full-blown open access) will not find much in the work of Elinor Ostrom and others employing her frameworks, theories, and models. As argued in the first part of this chapter, Ostrom's own normative commitments were few and contingent; her work on natural common-pool resources never argued as a general rule that common-property regimes were preferable to private, individual property systems or public property/regulatory systems. It was only in specific

\footnotetext{
${ }^{21}$ That is, of course, the primary lesson of Ostrom's Governing the Commons (1990).

22 Arguably, "open access" is optimal (that is, preferable to all alternative property/regulatory systems) for natural resource commons only so long as the rate of demand remains quite low relative to the supply - that is to say, prior to some known or presumed congestion point. See Cole (2002); Frischmann (2012: ch. II).
} 
circumstances that we might (or might not) find that one type of property/regulatory regime functioned as well as or better than others. She would surely caution IP scholars not to expect to find panacea solutions for problems of the information or knowledge commons.

\section{Acknowledgments}

In 20II, Lin Ostrom and I traveled together to the conference that resulted in this book. This chapter, though a poor substitute for what was to have been Lin's contribution to the volume, is dedicated to her memory. I am grateful to Brett Frischmann and Mike McGinnis for several helpful comments and suggestions.

\section{References}

James M. Acheson, Ostrom for Anthropologists, 5 INT'L J. Commons (Sept. 5, 20II), http://www. thecommonsjournal.org/index.php/ijc/article/view/245/209.

Masahiko Aoki, Toward a Comparative Institutional Analysis (MIT Press 200i). Douglas G. Baird, Robert H. Gertner, \& Randall C. Picker, Game Theory and THE Law (Harvard University Press 1998).

C. Dustin Becker \& Elinor Ostrom, Human Ecology and Resource Sustainability: The Importance of Institutional Diversity, 26 Ann. Rev. Ecology \& Systematics inz (1995)

Kent C. Berridge, Irrational Pursuits: Hyper-Incentives from a Visceral Brain, in THE Psychology of Economic Decisions, Vol. I: Rationality and Well-Being i7 (Isabelle Brocas \& Juan D. Carillo eds., Oxford University Press 2003).

James Boyle, The Second Enclosure Movement and the Construction of the Public Domain, 66 LAW \& Contemp. Probs. 33 (2003).

R. H. Coase, The Lighthouse in Economics, 17 J. LAW \& Economics 357 (1974).

Daniel H. Cole, Pollution and Property: Comparing Ownership Systems for Environmental Protection (Cambridge University Press 2002).

Daniel H. Cole, The Varieties of Comparative Institutional Analysis, 2013 WISCONSIN L. ReV. 383. Panos Constantinidis, Perspectives and Implications for the Development of INFORMATION INFRASTRUCTURES 43 (IGI Global 2OI2).

Jorge L. Contreras, Bermuda's Legacy: Policy, Patents, and the Design of the Genome Commons, I2 Minnesota J.L. Sci. \& Tech. 6i (2OiI).

Michael Cox, Gwen Arnold, \& Sergio Villamayor Tomás, A Review and Reassessment of Design Principles for Community-based Natural Resource Management, Is ECOlOgy \& SOCIETY 38 (2010).

Paul E. David, The Economic Logic of "Open Science" and the Balance between Private Property Rights and the Public Domain in Scientific Data and Information: A Primer, in The Role of the Public Domain in Scientific and Technical Data and Information ig (Julie M. Esanu \& Paul F. Uhlir eds., National Academies Press 2003).

Decentralization: A Sampling of Definitions, Working Paper Prepared in Connection with the Joint UNDP_-Government of Germany Evaluation of the UNDP Role in Decentralization 
66 Governing Knowledge Commons

and Local Governance (Oct. 1999), http://web.undp.org/evaluation/documents/decentralization_working_report.pdf.

Robert C. Ellickson, Order without law: How Neighbors Settle Disputes (Harvard University Press 1991).

Yuval Feldman \& Janice Nadler, The Law and Norms of File Sharing, 43 SAN Diego L. Rev. 577 (2006).

Lawrence M. Friedman, The Legal System: A Social Science Perspective (Russell Sage 1975).

Brett Frischmann, Infrastructure: The Social Value of Shared Resources (Oxford University Press 20I2).

Brett Frischmann, Two Enduring Lessons from Elinor Ostrom, 9 J. Institutional Economics 387 (2013).

Garrett Hardin, The Tragedy of the Commons, 162 SCIENCE 1243 (1968).

Michael Heise, The Past, Present, and Future of Empirical Legal Scholarship: Judicial Decision Making and the New Empiricism, 2002 U. IllinoIs L. ReV. 819 (2002).

Charlotte Hess, A Resource Guide for Authors: Open Access, Copyright, and the Digital Commons, CPR DigeST (March 2005), http://www.iasc-commons.org/sites/all/Digest/cpr72.pdf.

Charlotte Hess, Mapping the New Commons, presented at "Governing Shared Resources: Connecting Local Experience to Global Challenges," the i2th Biennial Conference of the International Association for the Study of the Commons, University of Gloucestershire, Cheltenham, England (July I4-I8, 2008), http://dlc.dlib.indiana.edu/dlc/ handle/10535/304.

Charlotte Hess \& Elinor Ostrom, Ideas, Artifacts, and Facilities: Information as a Common-Pool Resource, 66 Law \& Contemp. Probs. III (2003).

Charlotte Hess \& Elinor Ostrom, A Framework for Analysing the Microbiological Commons, 58 Int'L Social SCience J. 335 (2006).

Charlotte Hess \& Elinor Ostrom eds., Understanding Knowledge as a Commons: From Theory to Practice (MIT Press 2007).

Edward C. Hettinger, Justifying Intellectual Property, i8 Philosophy \& Public Affairs 3 I (1989).

Toni Honoré, Ownership, in Oxford Essays in Jurisprudence 107 (A. G. Guest ed., Oxford University Press 1961).

Justin Hughes, The Philosophy of Intellectual Property, 77 Georgetown L.J. 287 (1988).

Christopher Kinston \& Gonzalo Caballero, Comparing Theories of Institutional Change, $5 \mathrm{~J}$. InSTITUTIONAL ECONOMICS IsI (2009).

Neil K. Komesar, Imperfect Alternatives: Choosing Institutions in LaW (University of Chicago Press 1994).

Simon Kuznets, Economic Growth and Structure: Selected Essays (Norton 1965). William M. Landes \& Richard A. Posner, The Political Economy of Intellectual Property Law (Harvard University Press 2004).

Richard Lempert \& Joseph Sanders, An Invitation to Law and Social Science (Longman 1986).

David Lewis, Convention: A Philosophical Study (Harvard University Press 1969). Karl N. Llewellyn, Law and the Social Sciences-Especially Sociology, I 4 AmER. Sociological REVIEW 4I (1949). 
Michael J. Madison, Brett M. Frischmann, \& Katherine J. Strandburg, Constructing Commons in the Cultural Environment, 95 CORNELL L.Rev. 657 (2010).

Gerard Magliocca, Blackberries and Barnyards: Patent Trolls and the Perils of Innovation, 82 Notre Dame L. Rev. I809 (2013).

James F. McDonough III, The Myth of the Patent Troll: An Alternative View of the Function of Patent Dealers in an Idea Economy, 56 EMORY L.J. 189 (2006).

Michael D. McGinnis, An Introduction to IAD and the Language of the Ostrom Workshop: A Simple Guild to a Complex Framework, 39 Policy Studies J. 169 (2011).

John Monahan \& W. Laurens Walker, Social Science in Law (7th ed., Foundation Press 2009).

Douglass C. North, Institutions, Institutional Change, and Economic Performance (Cambridge University Press 1990).

Elinor Ostrom, Governing the Commons: The Evolution of Institutions for Collective Action (Cambridge University Press 1990).

Elinor Ostrom, Understanding Institutional Diversity (Princeton University Press 2005).

Elinor Ostrom, A Diagnostic Approach for Going beyond Panaceas, i०4 Proceedings of the National Academy of Sciences U.S. i5i8i (2007).

Elinor Ostrom, Polycentric Systems as One Approach to Solving Collective-Action Problems, in Climate Change and Sustainable Development: New Challenges for Poverty Reduction 17 (M.A. Mohamed Salih ed., Edward Elgar Publishing 2009a).

Elinor Ostrom, A Polycentric Approach for Coping with Climate Change, World Bank Policy Research Paper 5095 (Oct. 2009b).

Elinor Ostrom, A Long Polycentric Journey, iz Ann. Review Political Science i (2010a).

Elinor Ostrom, Polycentric Systems for Coping with Collective Action and Global Environmental Change, 20 Global Envtl. Change 550 (2010b).

Elinor Ostrom, Beyond Markets and States: Polycentric Governance of Complex Economic Systems, ioo Amer. Economic Review 64i (2010c).

Elinor Ostrom, Institutional Analysis and Development: Elements of the Framework in Historical Perspective, in Historical Developments and Theoretical Approaches in Sociology (C. Crothers ed.), vol. II, UNESCO Encyclopedia of Life Support SYSTEMS (UNESCO-ELOSS 2oiod).

Elinor Ostrom, Background on the Institutional Analysis and Development Framework, 39 POLICY Studies J. 7 (20II).

Elinor Ostrom, The Challenges of Achieving Conservation and Development, The Annual Proceedings of the Wealth and Well-Being of Nations, Vol. IV (Emily Chamlee-Wright ed., Beloit College 20II-2012).

Elinor Ostrom, Nested Externalities and Polycentric Institutions: Must We Wait for Global Solutions to Climate Change before Taking Actions at Other Scales?, 49 Economic Theory 353 (20I2).

Elinor Ostrom \& Sue Crawford, Classifying Rules, in Elinor Ostrom, Understanding Institutional Diversity i86 (Princeton University Press 2005).

Elinor Ostrom \& Charlotte Hess, A Framework for Analyzing the Knowledge Commons, in Understanding Knowledge as a Commons: From Theory to Practice 4i (Charlotte Hess \& Elinor Ostrom eds., MIT Press 2007). 
68 Governing Knowledge Commons

Elinor Ostrom, Marco A. Janssen, \& John M. Anderies, Going Beyond Panaceas, 104 Proceedings of the National Academy of Sciences U.S. 15176 (2007).

Elinor Ostrom, Roger Parks, \& Gordon Whitaker, Patterns of Metropolitan Policing (Ballinger Pub. Co. 1978).

Vincent Ostrom, Polycentricity, in Polycentricity and Local Public Economies: Readings from the Workshop in Political Theory and Policy Analysis (M. McGinnis, ed., University of Michigan Press 1999).

Vincent Ostrom \& Elinor Ostrom, Public Goods and Public Choices, in Polycentricity and Local Public Economies: Readings from the Workshop in Political Theory and Policy Analysis (M. D. McGinnis ed., University of Michigan Press 1999).

Vincent Ostrom, Charles M. Tiebout, \& Charles Warren, The Organization of Government in Metropolitan Areas: A Theoretical Inquiry, 55 Amer. Political Science Rev. 83i (196i).

Richard A. Posner, The Constitutionality of the Copyright Term Extension Act: Economics, Politics, Law and Judicial Technique, in Eldred v. Ashcroft, 2003 The Supreme Court Rev. 143 (2003).

Roscoe Pound, Law in Books and Law in Action, 44 Amer. L. ReV. I2 (I910).

H. Laurence Ross, Settled Out of Court: The Social Process of Insurance Claims Adjustment 179 (Rev. 2d ed., De Gruyter 1980).

Paul Sabatier, Theories of the Policy Process (2d ed., Westview Press 2007).

Edella Schlager \& Elinor Ostrom, Property-Rights Regimes and Natural Resources: A Conceptual Analysis, 68 Land EConomics 249 (1992).

Charles M. Schweik, An Institutional Analysis Approach to Studying Libre Software "Commons," 6 UPGRADE 17 (2005).

Charles M. Schweik \& Robert English, Tragedy of the FOSS Commons? Investigating the Institutional Designs of Free/Libre and Open Source Software Projects, I2 First MondaY no. 2 (Feb. 5, 2007), http://firstmonday.org/htbin/cgiwrap/bin/ojs/index.php/fm/article/ view/1619/1534.

Charles M. Schweik \& Meelis Kitsing, Applying Elinor Ostrom's Rule Classification Framework to the Analysis of Open Source Software Commons, 2 Transnat'l Corporations Rev. I3 (2010).

Herbert A. Simon, Models of Bounded Rationality, in Decision and Organization (C. B. McGuire \& Roy Radner eds., North-Holland 1972).

Alma Swan, Open Access and the Progress of Science, 95 Amer. Scientist 198 (2007).

Josh Tenenberg, An Institutional Analysis of Software Teams, 66 J. Human-Computer Studies $484(2008)$.

David E. Van Zandt, The Lesson of the Lighthouse: "Government" or "Private" Provision of Goods, 22 J. Legal STudies 47 (1993).

R. Polk Wagner, Information Wants to Be Free: Intellectual Property and the Mythologies of Control, io3 Columbia L. Rev. 995 (2003).

John Willinsky, The Access Principle: The Case for Open Access to Research and SChOlarship (MIT Press 2006). 